\title{
シミュレーション解析による水中ドルフィンキック時の 足関節底屈角度の増加がパフォーマンスに与える影響
}

\section{杉本 誠二 ${ }^{1)}$ 中島 求 $^{2)}$ 市川 浩 $^{3)}$ 三輪 飛寛 ${ }^{1)}$ 武田 剛 ${ }^{1)}$ 野村 武男 ${ }^{4}$}

Seiji Sugimoto ${ }^{1}$, Motomu Nakashima ${ }^{2}$, Hiroshi Ichikawa ${ }^{3}$, Takahiro Miwa ${ }^{1}$, Tsuyoshi Takeda ${ }^{1}$ and Takeo Nomura ${ }^{4}$ : The effects of plantar flexion angle increment on the performance during underwater dolphin kick using simulation analysis. Japan J. Phys. Educ. Hlth. Sport Sci. 53 : 51-60, January, 2008.

Abstract : The purpose of this study was to investigate the relationship between plantar flexion angle and underwater dolphin kick performance using a simulation model, SWUM (SWimming hUman Model), in which the entire body was represented as a series of elliptic cylinders. Three unsteady fluid forces (added mass force, normal and tangential resistive force), buoyancy and gravity acting on the elliptic cylinders were computed from the shape and density of the cylinders, and from the joint motion for one cycle. Eight elite competitive swimmers participated in this study. Their body characteristics were measured and input as the simulation data (the shape and density of the elliptic cylinders). The joint motion data for one cycle were obtained by the 2-D DLT method during the underwater dolphin kick. To recreate the dynamics of the underwater dolphin kick in the simulation, three fluid coefficients, used to calculate the three unsteady fluid forces, were identified to minimize the difference between measured and simulated swimming velocity by the least-squares method. This identification was conducted for each of the input data. Simulations of the increased plantar flexion angle in the knee extension phase were executed with the optimal fluid coefficients for each swimmer in order to analyze the change in swimming velocity and thrust generated by the feet. The conclusions can be summarized as follows : (1) Swimming velocity during the underwater dolphin kick increased due to the increment of the thrust generated by the feet after an increase in the plantar flexion angle. (2) It was suggested that flexibility of plantar flexion is important, although it is not a determinant of underwater dolphin kick performance. (3) Swimmers with low flexibility of plantar flexion tended to achieve a faster swimming velocity after increasing the plantar flexion angle.

Key words : fluid dynamics, thrust, flexibility, swimming

キーワード : 流体動力学, 推進力, 柔軟性, 競泳

1）筑波大学大学院博士課程人間総合科学研究科 干305-8574 茨城県つくば市天王台 1-1-1

2) 東京工業大学大学院情報理工学研究科 干152-8552 東京都目黑区大岡山 2-12-1

3）国立スポーツ科学センタースポーツ情報研究部 干115-0056 東京都北区西が丘 3-15-1

4) 筑波大学人間総合科学研究科

干305-8574 茨城県つくば市天王台 1-1-1 連絡先 杉本誠二
1. Graduate School of Comprehensive Human Sciences, University of Tsukuba

1-1-1 Tennodai, Tsukuba, Ibaraki 305-8574

2. Department of Mechanical and Environmental Informatics, Tokyo Institute of Technology

2-12-1 Ookayama, Meguro-ku, Tokyo 152-8552

3. Department of Sports Information, Japan Institute of Sports Sciences

3-15-1 Nishigaoka, Kita-ku, Tokyo 115-0056

4. Comprehensive Human Sciences, University of Tsukuba

1-1-1 Tennodai, Tsukuba, Ibaraki 305-8574

Corresponding author Sugimoto@swim.taiiku.tsukuba. $a c . j p$ 


\section{I 緒言}

競泳競技に打いて，スタートおよびターン後, クロールとバタフライでは水中ドルフィンキック を，背泳ぎでは仰向け姿勢で水中ドルフィンキッ クを行い，水面へ浮き上がった時点で各泳法のス トロークを始める。スタートおよびターン後の水 中ドルフィンキックは最大 $15 \mathrm{~m}$ までとされ，50 $\mathrm{m}$ プールで行われるレースで 3 割, $25 \mathrm{~m}$ プール でのレースで 6 割の距離を水中ドルフィンキック によって推進することが許されている。よって, 競泳競技のパフォーマンスに対する水中ドルフィ ンキックの貢献は非常に大きい. 2006 年のルール 改正により, 平泳ぎでもスタートおよびターン後 に 1 回の水中ドルフィンキックの使用が認められ た.このことにより, 今日では全ての泳法で水中 ドルフィンキックが用いられている．水中ドル フィンキックについて Sugimoto et al. (2006, pp. 100-102) は, 中島ほか (2005, pp. 1361-1369) によって開発された水泳人体シミュレーションモ デル (SWimming hUman Model, 以下 $\lceil\mathrm{SWUM}$ 」と略す）を応用することで，シミュ レーション上で水中ドルフィンキックのダイナミ クスを再現し, 水中ドルフィンキックの推進力は 主に足部によって発揮されていることを示した。 SWUM は水泳中に全身各部位に働く非定常流体 力を考慮し, 全身のダイナミクスを詳細に表現す ることができる。このシミュレーションモデルの 妥当性については, 既に中島ほか (2005, pp. 1361 -1369）によって確認され, 報告されている. 水中 で四肢を動かし，形状を変えながら推進する場合 の流体力を正確に測定することはきわめて困難で あるため, 今までの水泳を対象とした力学的研究 では，手部のみ，もしくは手部之前腕といった身 体の一部分を対象にした分析（Schleihauf et al., 1988 ; Berger et al., 1995 ; Sanders, 1999 ; Bixler et al., 2002 ; Abel et al., 2006）が主であり，実際 の泳動作が行われる非定常流体環境を考慮し, 全 身各部位に働く流体力を詳細に分析したものは見 当らない，そのため, SWUM を応用した Sugi- moto et al. (2006, pp. 100-102）の報告により, 初めて泳動作中のキネティクス情報からキックに おける足部の重要性が明らかにされた。フラッ ターキック（通常のバタ足）のパフォーマンスに ついては静的な足関節の底屈角度との関係が報告 されているが，相関があるという報告 (大庭ほか, 1995）と相関がないという報告（Mookerjee et al., 1995）がある。 それにも関わらず，キックのパ フォーマンスに対する足部の重要性は選手やコー チの間で強く認識されており，泳中の足関節底屈 角度を向上させることで効率よく推進力が得られ る (Counsilman et al., 1977 ; Maglischo, 1993, pp. 426-428）と考えられているため，足関節底屈 角度を増加させる柔軟性トレーニングがコーチン グ現場では一般的に行われている。しかし，ヒト を対象とした場合，動作を変えずに足関節底屈角 度だけを変化させて泳ぐことが非常に困難である ため, 泳中の足関節底屈方向への動的な柔軟性向 上がキックにおけるパフォーマンスの改善にどれ だけ貢献するかについて，未だ明らかにされてい ない。

そこで本研究では, 水泳人体シミュレーション モデル SWUM 上に水中ドルフィンキックのダイ ナミクスを再現し, 泳中の足関節底屈角度のみを 増加させたときの泳速度変化抢よび, 泳中の最大 底屈角度と泳速度の関連を分析することにより, 泳中の動的な足関節底屈角度とパフォーマンスと の関係を明らかにすることを目的とした。

\section{II 方法}

\section{1. 被験者}

大学水泳部に所属し, 日本学生選手権出場レベ ルである男子競泳選手 8 名 (年齢 $21.4 \pm 1.1$ 歳, 身 長 $173.6 \pm 9.0 \mathrm{~cm}$, 体重 $70.0 \pm 8.7 \mathrm{~kg}$ ）を被験者と した。被験者には事前に実験の趣旨と内容，およ び危険性についての説明を行い，書面にて参加の 同意を得た。

\section{2. 身体を表す楕円柱の形状と密度の算出}

シミュレーションモデルでは, Fig. 1のように 


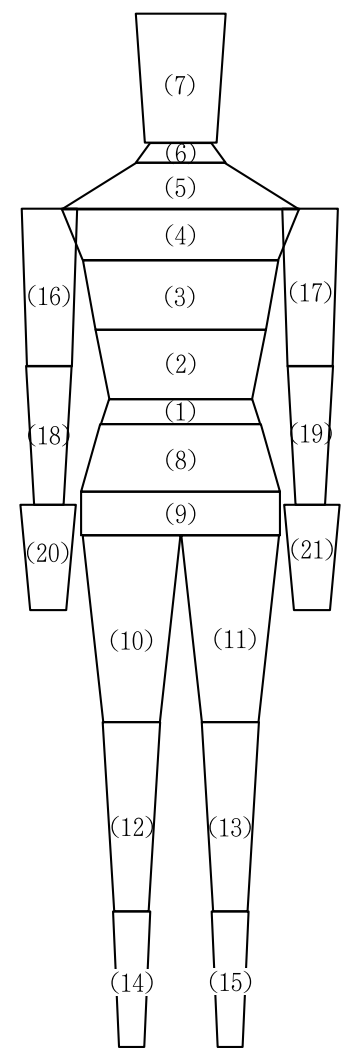

No. 1 : Lower waist

No. 2 : Upper waist

No. 3 : Lower breast

No. 4 : Upper breast

No. 5 : Shoulder

No. 6 : Neck

No. 7 : Head

No. 8 : Upper hip

No. 9 : Lower hip

No.10 : Right thigh

No.11 : Left thigh

No.12 : Right shank

No.13 : Left shank

No.14 : Right foot

No.15 : Left foot

No.16 : Right upper arm

No.17 : Left upper arm

No.18 : Right forearm

No.19 : Left forearm

No.20 : Right hand

No.21 : Left hand

Fig. 1 Correspondence between elliptic cylinder elements and human body parts.

ヒトの身体各部位を 21 個の楕円柱要素に対応付 けているため，中島ほか（2005，pp. 1361-1369） の方法に従い，各棈円柱要素の上端と下端それ ぞれの短径と長径を被験者の形態測定結果から算 出した，各楕円柱要素の密度については，被験者 の体重と日本人アスリートの身体部分慣性係数 （阿江ほか, 1992，pp. 22-33）の質量比により各楕 円柱要素の質量を算出し, 形状より求めた各楕円 柱要素の体積で割ることで算出した，胴体部に対 しては水泳時の肺の残気量に依存して働く浮力の 影響を考慮するため, 高木・岡本 (1968) の結果 を参考にして，水泳時の肺の残気量を被験者の肺 活量の 4 分の 1 と仮定した. 胴体部の棈円柱要素 のうち肺を含む胸部の楕円柱要素の密度を肺の残 気量分減少させ，胴体部全体の質量比を維持する ために胴体部の他の楕円柱要素の密度を増加させ た.

\section{3. 泳動作の 1 周期関節運動の解析}

泳動作の入力データとして， 1 周期分の関節運 動である各楕円柱要素間の角度変位を算出するた め, 水中ドルフィンキックを対象とした動作分析 を行った。水中ドルフィンキックは主に矢状面で の動作であり，ほぼ左右対称の動作であるので, 泳者側方からの 2 次元で動作を分析した。被験者 には分析の目印として, 頭頂, 右耳珠点, 胸骨上 縁, 肋骨下端, 右肩, 右肘, 右手首, 尺側右中手 指節関節, 右大転子, 右膝, 右腓骨外果, 右踵に 白いビニールテープでマーキングを行った，試技 は被験者の主観による 2 種類の泳速度（Slow， Fast) で行った. 1 台の CCD カメラ (Victor 社製 ; TK-C1381）をプール側面の水中空に固定し, 水中 映像を撮影した。サンプリング周波数は $60 \mathrm{fps}$, 露出時間は $1 / 250 \mathrm{~s}$ とした. 画像分析ソフト (DKH 社製；Frame DIAS II）を用い，DLT 法により身 体右側の 2 次元座標を算出し, 2 次の Butter- 
worth 特性を有するデジタルフィルタによる平 滑化を遮断周波数 $6 \mathrm{~Hz}$ で行い，1 周期分の各関節 の角度变位を算出した。左側の各関節の角度変位 は右側の分析結果を用いた。身体重心座標は阿江 ほか（1992，pp. 22-33）の身体部分慣性係数を用 いて算出し，身体重心速度はラグランジェの多項 式を用いた数值微分によって算出した.

\section{4. シミュレーションの計算条件}

本シミュレーションではまず，七トの身体形状 とともに, 泳動作である 1 周期分の関節運動の時 系列デー夕をすべての関節自由度について与え る。 そして，身体全体の位置，慣性主軸の向き， 絶対速度および絶対角速度についての初期值を与 える。次にこの初期の瞬間において，ヒトを表す 21 個の楕円柱要素の位置, 姿勢, 絶対速度 (身体 全体の絶対速度に関節運動による相対速度が加え られた速度）から，各楕円柱要素に働く流体力が 算出され，それらの合計により，身体全体に働く 流体力および流体力によるモーメントが算出され る。そして，ルンゲ・クッ夕法が適用された，身 体全体のニュートン・オイラー法による並進と回 転の運動方程式に，これらの流体力とモーメント が代入され，微少時間後の新たな身体全体の重心 位置と速度および慣性主軸の向きと角速度が算出 される．微少時間後の次の時間ステップにおいて も以上と同様の計算が繰り返され, 時間が進行さ れる。この計算の流れは 1 周期分，さらには重心 の速度が収束するまで繰り返される。ここで考慮 される各棈円柱要素への外力は, 付加質量による 慣性力, 楕円柱長手軸に対する法線・接線方向抵 抗力, 浮力, 重力であり, これらの外力のうち浮 力以外は，楕円柱を長手軸方向に分割した微小楕 円板一つ一つについて計算され，微小楕円板の中 心に作用すると仮定されている。よってこれらの 外力については，楕円柱の上端面での効果は特に 計算されない，一方浮力については，楕円柱の側 面と上下端面全てを長手軸方向と円周方向につい て微小四辺形に分割し，それぞれに働く静水圧を 数值積分して計算される。本研究では中島ほか （2005，pp. 1361-1369）によって設定された楕円
柱要素の分割数を用い，長軸方向に 10 , 円周方向 に 36 とした。分析の時間刻みは $0.01 \mathrm{~s}$ とし，重心 の初期速度は $0 \mathrm{~m} / \mathrm{s}$ とした. シミュレーションの 前提条件として，水中ドルフィンキックは 1 周期 を通して全身が水中で動作しなければならない． そのため, 重心の初期位置を被験者の身長の半分 の水深とした. 水中では物体の運動や形態の違い により, 物体周りの渦の生成や剥離の仕方が変化 し，それに伴って物体に働く流体力が複雑に変化 する。この非定常性を考慮するため，各楕円柱要 素に働く 3 つの非定常流体力（付加質量による慣 性力と法線・接線方向抵抗力）算出に，それぞれ 1 つずつの非定常流体力係数が用いられている. よって, 水中ドルフィンキックのダイナミクスを シミュレーション上で再現するには，入力デー夕 に合った非定常流体力係数を同定しなければなら ない，各被験者の各試技に合った非定常流体力係 数の同定には, Sugimoto et al., (2006, pp. 100102）と同様に非線形最適化手法である滑降シン プレックス法を用い，動作分析から求めた 1 周期 の泳速度推移とシミュレーションによって算出し た值の差分が最小となるように各係数を決定し た.

\section{5. 足関節底屈角度を変化させた水泳人体シミュ レーション}

水中ドルフィンキックでは, 膝の伸展動作で足 関節が底屈することにより水が後方へと押し出さ れ (Maglischo, 1993, pp. 426-428), 膝の伸展局面 に扔いて足部で大きな推進力が発揮される（Sugimoto, 2006, pp. 100-102）ことが既に明らかにさ れている. 本研究では泳中の足関節底屈角度増加 に伴う泳速度変化を分析するため，実測した形状 と運動を入力データとしたシミュレーション（以 下 $\left\lceil\mathrm{S}_{\mathrm{A} 0} 」\right.$ と略す）と，推進力が主に発揮される膝 の伸展局面の足関節底屈角度のみを Fig. 2 に示 す通りに $1^{\circ} ， 3^{\circ} ， 5^{\circ}$ の 3 段階に増加させたシミュ レーション（以下それぞれ「 $\left.\left.\mathrm{S}_{\mathrm{A} 1}\right\lrcorner, 「 \mathrm{~S}_{\mathrm{A} 3}\right\rfloor,\left\lceil\mathrm{S}_{\mathrm{A} 5}\right\rfloor$ と略す）を実行し，泳速度と足部によって発揮さ れた推進力に関して $\mathrm{S}_{\mathrm{A} 0}$ の值と $\mathrm{S}_{\mathrm{A} 1}, \mathrm{~S}_{\mathrm{A} 3}, \mathrm{~S}_{\mathrm{A} 5}$ の值 を比較した。ここで足関節の角度とは, 膝と外果, 


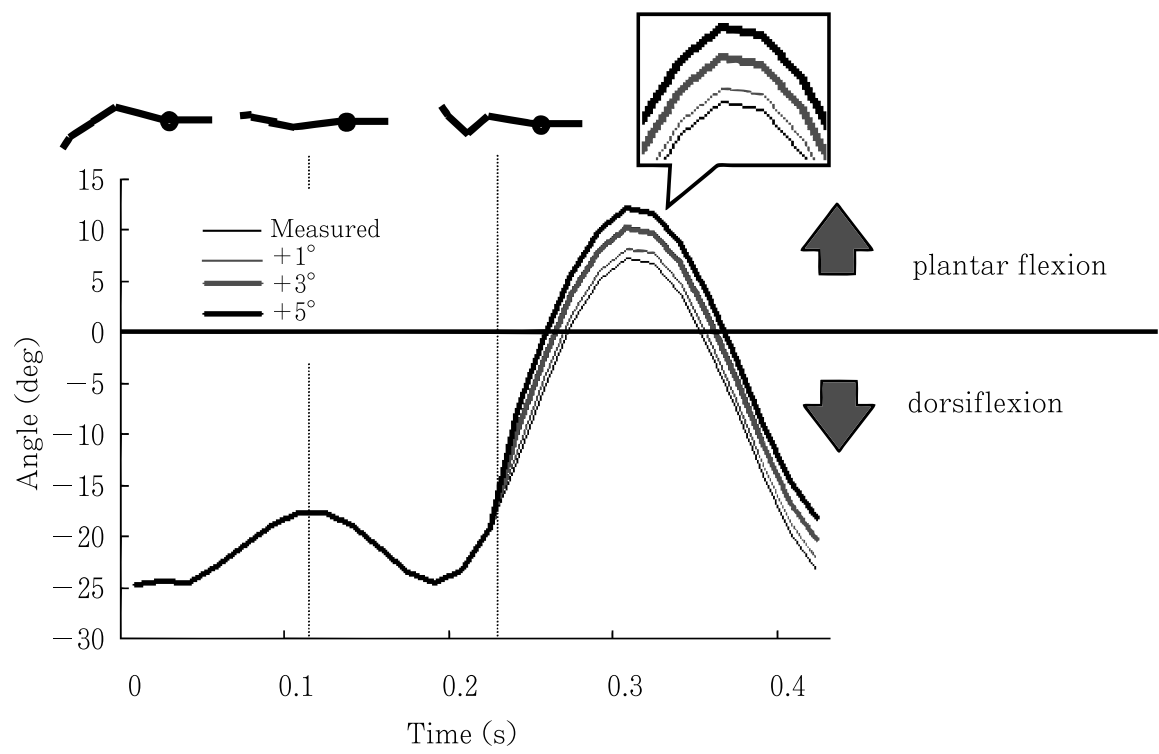

Fig. 2 Ankle angle changes for one cycle during under water dolphin kick at fast trial in Sub. Ka. The stick pictures above the graph show the phase of the underwater dolphin kick motion. The left stick picture shows the end of the knee extension phase. The stick picture at center shows the beginning of the knee flexion phase. The right stick picture shows the beginning of the knee extension phase.

そして足の指先を結んだ線が一直線になる状態を $0^{\circ}$ とし, その状態からの底屈を正, 背屈を負とす る。また，具体的なパフォーマンスへの影響を調 査するために $10 \mathrm{~m}$ 所要時間の比較も行った。 こ の $10 \mathrm{~m}$ とは, スタート後の飛び込み動作とター ン後のけ伸び動作を考慮した，実際のレースでス タートおよびターン後に行われていると考えられ る水中ドルフィンキックの泳距離に相当する.

\section{6. 統計処理}

泳中の足関節底屈角度の増加によって, 泳速 度, $10 \mathrm{~m}$ 所要時間, 推進力が向上するか否かを検 証するために, 8 名分の 1 周期泳速度, $10 \mathrm{~m}$ 所要 時間，足部による推進力それぞれの平均值を算出 し，条件間の平均値の差の検定に多変量分散分析 を用いた多重比較（ダネット検定）を行った。ま た, 泳中の足関節底屈方向への動的な柔軟性と泳 速度の関係，さらには柔軟性の向上に伴う泳速度 変化が泳者本来の足関節の動的な柔軟性に依存す るか否かを検証するため, 動作分析から求めた 1 周期中の足関節最大底屈角度と $\mathrm{S}_{\mathrm{A} 5}$ の泳速度変化
との関係について，ピアソンの相関分析を行っ た。いずれも有意水準は $5 \%$ とした。

\section{III 結果}

\section{1. 水中ドルフィンキックのダイナミクス}

1 周期分の水平方向泳速度推移に関する実測值 と $\mathrm{S}_{\mathrm{A} 0}$ の值の比較例として, 被験者 Ka (Fast 条 件）の結果を Fig. 3 に示し, 経時時間に対応する 水中動作を表すスティックピクチャを合わせて図 示した. 1 周期を通して実測と $\mathrm{S}_{\mathrm{A} 0}$ による泳速度 推移はほぼ一致し, 膝の屈曲動作で減少, 膝の伸 展動作で増加がみられた。他の被験者の試技にお いても，実測と $\mathrm{S}_{\mathrm{A} 0}$ による泳速度推移はほぼ一致 していた. 1 周期分の水平方向平均泳速度に関し て，Slowに扔ける被験者の平均は実測值が 1.09 $\pm 0.14 \mathrm{~m} / \mathrm{s}, \mathrm{S}_{\mathrm{A} 0}$ の值が $1.10 \pm 0.14 \mathrm{~m} / \mathrm{s}$, Fastにお ける実測值が $1.61 \pm 0.18 \mathrm{~m} / \mathrm{s}, \mathrm{S}_{\mathrm{A} 0}$ の值が $1.61 \pm$ $0.17 \mathrm{~m} / \mathrm{s}$ であった. 以上の結果から, 全被験者の 全試技に関して, 水中ドルフィンキックのダイナ ミクスをシミュレーション上でほぼ再現できたと 


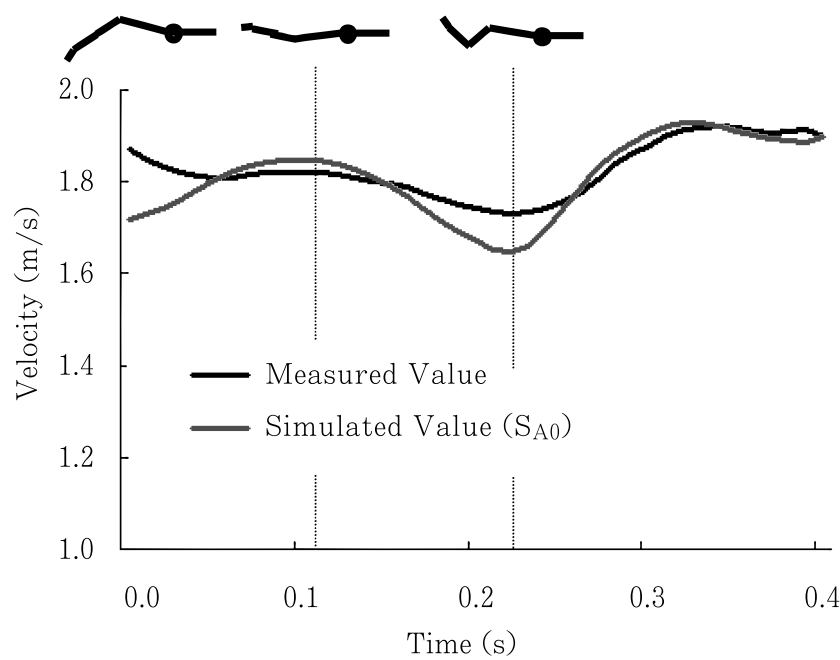

Fig. 3 Velocity changes for one cycle during under water dolphin kick at fast trial in Sub. Ka. The stick pictures above the graph show the phase of the underwater dolphin kick motion. The left stick picture shows the end of the knee extension phase. The stick picture at center shows the beginning of the knee flexion phase. The right stick picture shows the beginning of the knee extension phase.

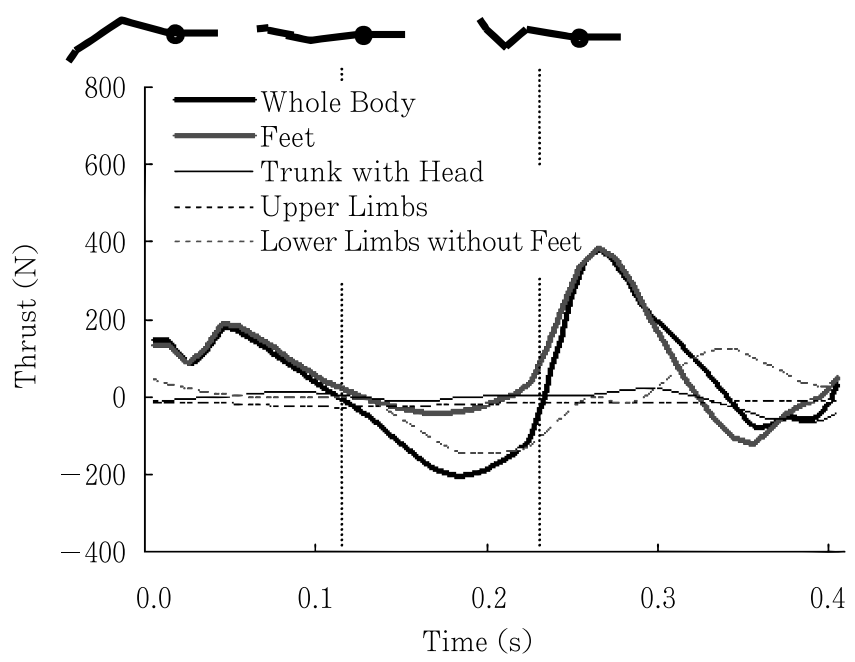

Fig. 4 Thrust change generated by each body part for one cycle during under water dolphin kick at fast trial in Sub. Ka. The stick pictures above the graph show the phase of the underwater dolphin kick motion. The left stick picture shows the end of the knee extension phase. The stick picture at center shows the beginning of the knee flexion phase. The right stick picture shows the beginning of the knee extension phase.

思われる。

Fig. 4 は被験者 Ka（Fast 条件）における各身 体部位によって発揮された 1 周期水平方向推進力
推移を示したものである， 1 周期を通して全身と 足部で発揮された推進力は同様の推移をし, 共に 膝屈曲動作で最小値, 膝伸展動作で最大值を示し 
Table 1 Velocity and $10 \mathrm{~m}$ time change by increment in plantar flexion.

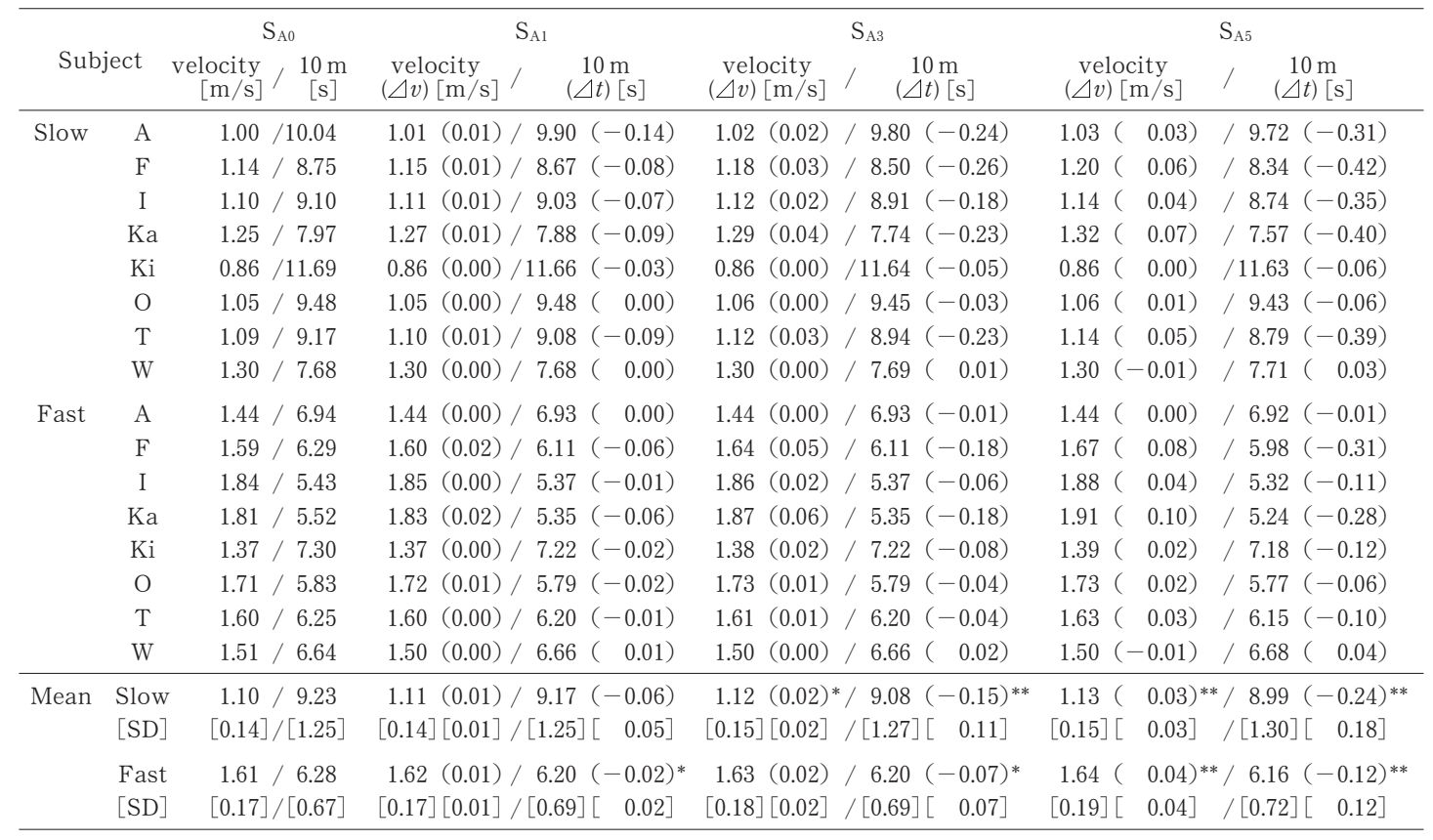

${ }^{*} \mathrm{p}<0.05 ;{ }^{* *} \mathrm{p}<0.01$

ていた，頭を含めた体幹と上肢は $0.00 \mathrm{~N}$ を基準に ほとんど変化していなかった。これらの特徽は全 被験者の全試技で同様に観察され，水中ドルフィ ンキックの推進力は主に足部によって発揮されて いた。

\section{2. 足関節屈角度変化による泳速度変化}

$\mathrm{S}_{\mathrm{A} 0}, \mathrm{~S}_{\mathrm{A} 1}, \mathrm{~S}_{\mathrm{A} 3}, \mathrm{~S}_{\mathrm{A} 5}$ それぞれで求めた 1 周期分の 水平方向平均泳速度と泳速度から求めた $10 \mathrm{~m}$ 所 要時間を Table 1 に示した.ここで示す $\Delta v$ と $\Delta t$ とは, 泳速度と $10 \mathrm{~m}$ 所要時間に関する $\mathrm{S}_{\mathrm{A} 0}$ と $\mathrm{S}_{\mathrm{A} 1}$, $\mathrm{S}_{\mathrm{A} 3}, \mathrm{~S}_{\mathrm{A} 5}$ との差である. Slow における泳速度変化 の平均は, $\mathrm{S}_{\mathrm{A} 1}$ で $0.01 \pm 0.01 \mathrm{~m} / \mathrm{s}(\mathrm{p}>0.05), \mathrm{S}_{\mathrm{A} 3}$ で $0.02 \pm 0.02 \mathrm{~m} / \mathrm{s} \quad(\mathrm{p}<0.05), \quad \mathrm{S}_{\mathrm{A} 5}$ で $0.03 \pm 0.03 \mathrm{~m} / \mathrm{s}$ $(\mathrm{p}<0.01)$ と, $\mathrm{S}_{\mathrm{A} 1}$ を除いて有意に増加していた。

Fast の泳速度変化の平均值は, それぞれ $0.01 \pm$ $0.01 \mathrm{~m} / \mathrm{s} \quad(\mathrm{p}>0.05), 0.02 \pm 0.02 \mathrm{~m} / \mathrm{s} \quad(\mathrm{p}>0.05)$, $0.04 \pm 0.04 \mathrm{~m} / \mathrm{s}(\mathrm{p}<0.01)$ と, $\mathrm{S}_{\mathrm{A} 5}$ で有意に増加し ていた. $10 \mathrm{~m}$ 所要時間の変化は, Slowにおける 平均值で $-0.06 \pm 0.05 \mathrm{~s}(\mathrm{p}>0.05),-0.15 \pm 0.11 \mathrm{~s}$ $(\mathrm{p}<0.01),-0.24 \pm 0.18 \mathrm{~s}(\mathrm{p}<0.01)$, Fast における
平均值で $-0.02 \pm 0.02 \mathrm{~s}(\mathrm{p}<0.05),-0.07 \pm 0.07 \mathrm{~s}$ $(\mathrm{p}<0.05), \quad-0.12 \pm 0.12 \mathrm{~s}(\mathrm{p}<0.01)$ と, Slow $\mathrm{S}_{\mathrm{A} 1}$ を除いて有意に短縮していた。つつり，足関 節底屈角度の増加に伴って泳速度は増加し, $10 \mathrm{~m}$ 所要時間は短縮していた。 ただし例外として, 被 験者 $\mathrm{W}$ においては足関節底屈角度の増加に伴っ て逆に泳速度は低下し, $10 \mathrm{~m}$ 所要時間は延長し ていた。

動作分析から求めた 1 周期中の足関節最大底屈 角度と泳速度の関係は, Slow（ $\mathrm{r}=0.11, \mathrm{p}>0.05)$ と Fast $(r=-0.29, \mathrm{p}>0.05)$ 両試技で有意な相関 関係は認められなかった。 次に, 足関節の底屈角 度増加に伴う泳速度変化が被験者本来の足関節の 動的な柔軟性に依存するか否かを検証した， 1 周 期足関節最大底屈角度と $\mathrm{S}_{\mathrm{A} 5}$ での泳速度変化との 関係を Fig. 5 に示した. 両変数間に Slow $(r=-0.86$, $\mathrm{p}<0.05)$ と Fast $(\mathrm{r}=-0.86, \mathrm{p}<0.01)$ 両試技で 有意な負の相関関係が認められ, 足関節の動的な 柔軟性が高い被験者ほど底屈角度増加に伴う泳速 度の増加は小さく, 柔軟性が低い被験者ほど底屈 角度増加に伴う泳速度の増加は大きかった。 
Table 2 Thrust change by increment in planter flexion.

\begin{tabular}{|c|c|c|c|c|c|}
\hline \multicolumn{2}{|c|}{ Subject } & $\begin{array}{c}\mathrm{S}_{\mathrm{A} 0} \\
\text { Thrust [N] }\end{array}$ & $\begin{array}{c}\mathrm{S}_{\mathrm{A} 1} \\
\text { Thrust }(\Delta t h)[\mathrm{N}]\end{array}$ & $\begin{array}{c}\mathrm{S}_{\mathrm{A} 3} \\
\text { Thrust }(\Delta t h)[\mathrm{N}]\end{array}$ & $\begin{array}{c}\mathrm{S}_{\mathrm{A} 5} \\
\text { Thrust }(\Delta t h)[\mathrm{N}]\end{array}$ \\
\hline \multirow[t]{8}{*}{ Slow } & $\mathrm{A}$ & 19.71 & $21.25(1.54)$ & $21.94(2.23)$ & $22.09(2.38)$ \\
\hline & $\mathrm{F}$ & 20.94 & $21.28(0.34)$ & $22.65(1.71)$ & $23.84(2.90)$ \\
\hline & I & 37.50 & $37.82(0.32)$ & $38.37(0.87)$ & $39.05(1.55)$ \\
\hline & $\mathrm{Ka}$ & 25.63 & $26.67(1.04)$ & $28.04(2.41)$ & $29.86(4.23)$ \\
\hline & $\mathrm{Ki}$ & 18.90 & $20.07(1.16)$ & $20.30(1.40)$ & $20.29(1.39)$ \\
\hline & $\mathrm{O}$ & 24.01 & $24.04(0.03)$ & $25.05(1.05)$ & $26.07(2.06)$ \\
\hline & $\mathrm{T}$ & 23.83 & $24.25(0.42)$ & $24.70(0.87)$ & $25.57(1.75)$ \\
\hline & $\mathrm{W}$ & 35.34 & $35.12(-0.22)$ & $34.29(-1.05)$ & $33.33(-2.00)$ \\
\hline \multirow[t]{8}{*}{ Fast } & A & 119.44 & $119.53(0.09)$ & $119.98(0.55)$ & $120.32(0.89)$ \\
\hline & $\mathrm{F}$ & 62.18 & $63.02(0.84)$ & $64.87(2.69)$ & $66.56(4.39)$ \\
\hline & I & 100.29 & $100.85(0.56)$ & $102.30(2.01)$ & $103.85(3.56)$ \\
\hline & $\mathrm{Ka}$ & 69.97 & $71.54(1.57)$ & $74.69(4.72)$ & $77.57(7.60)$ \\
\hline & Ki & 64.34 & $65.28(0.94)$ & $68.14(3.80)$ & $70.23(\quad 5.89)$ \\
\hline & $\mathrm{O}$ & 80.26 & $81.23(0.98)$ & $82.03(1.77)$ & $82.72(\quad 2.47)$ \\
\hline & $\mathrm{T}$ & 63.61 & $63.69(0.08)$ & $64.43(0.82)$ & $65.69(2.08)$ \\
\hline & W & 50.68 & $49.48(-1.20)$ & $48.40(-2.29)$ & $46.38(-4.31)$ \\
\hline \multirow[t]{4}{*}{ Mean } & Slow & 25.73 & $26.31(0.58)$ & $26.92(1.19) *$ & $27.51(1.78)^{* *}$ \\
\hline & {$[\mathrm{SD}]$} & {$[7.00]$} & {$\left[\begin{array}{ll}6.65\end{array}\right]\left[\begin{array}{ll}0.61\end{array}\right]$} & {$[6.35]\left[\begin{array}{ll}1.08\end{array}\right]$} & {$\left[\begin{array}{ll}6.25\end{array}\right]\left[\begin{array}{ll}1.78\end{array}\right]$} \\
\hline & Fast & 76.35 & $76.83(0.48)$ & $78.10(1.76)$ & $79.16(2.82) *$ \\
\hline & {$[\mathrm{SD}]$} & {$[22.84]$} & {$\left[\begin{array}{ll}22.97\end{array}\right]\left[\begin{array}{ll}0.84\end{array}\right]$} & {$[23.02]\left[\begin{array}{ll}2.16\end{array}\right]$} & {$[23.34]\left[\begin{array}{ll}3.60\end{array}\right]$} \\
\hline
\end{tabular}

${ }^{*} \mathrm{p}<0.05 ;{ }^{* *} \mathrm{p}<0.01$

\section{3. 足関節底屈角度変化による推進力変化}

泳速度と同様に，足部のみによって発揮された 1 周期分の水平方向平均推進力に関するシミュ レーション結果を Table 2 に示した.ここで示す $\Delta$ th $は \mathrm{~S}_{\mathrm{A} 0}$ と $\mathrm{S}_{\mathrm{A} 1}, \mathrm{~S}_{\mathrm{A} 3}, \mathrm{~S}_{\mathrm{A} 5}$ の推進力の差である.

Slowにおける足部で発揮された推進力変化の平 均は $\mathrm{S}_{\mathrm{A} 1}$ で $0.58 \pm 0.61 \mathrm{~N}(\mathrm{p}>0.05), \mathrm{S}_{\mathrm{A} 3}$ で $1.19 \pm$ $1.08 \mathrm{~N}(\mathrm{p}<0.05), \quad \mathrm{S}_{\mathrm{A} 5}$ で $1.78 \pm 1.78 \mathrm{~N}(\mathrm{p}<0.01)$ と, $\mathrm{S}_{\mathrm{A} 1}$ を除いて有意に増加していた. Fastにお ける平均值はそれぞれ $0.48 \pm 0.84 \mathrm{~N}(\mathrm{p}>0.05)$, $1.76 \pm 2.16 \mathrm{~N}(\mathrm{p}>0.05), 2.82 \pm 3.60 \mathrm{~N}(\mathrm{p}<0.05)$ と, $\mathrm{S}_{\mathrm{A} 5}$ で有意に増加していた。 多くの被験者で 足関節底屈角度の増加に伴い，足部によって発揮 された推進力は向上していたが，例外として被験 者 $\mathrm{W}$ のみ足関節底屈角度の増加に伴って足部に よる推進力は逆に減少していた。

\section{IV 考察}

本シミュレーション解析により水中ドルフィン キックでは主に足部で推進力が発揮されている (Fig. 4) ことが明らかにされ，この結果はSugimoto et al.（2006，pp. 100-102）の結果を支持す るものであった。 また, 足関節底屈角度を増加さ せることで水中ドルフィンキックの泳速度は向上 し，底屈角度の増加が大きいほど泳速度の向上は 大きく，それに伴って $10 \mathrm{~m}$ 所要時間も短縮する ことが明らかとなった（Table 1)。本研究では主 な推進力発生源である足部の関節底屈角度のみを 変化させたシミュレーションを実行した結果, 足 部によって発揮された推進力が増加した（Table 2). そのため, 底屈角度増加に伴う泳速度の向上 は足部の推進力増加によって達成されたと考えら れる. 泳速度の向上による $10 \mathrm{~m}$ 所要時間の短縮 は，スタートやターンごとの時間短縮が可能であ 


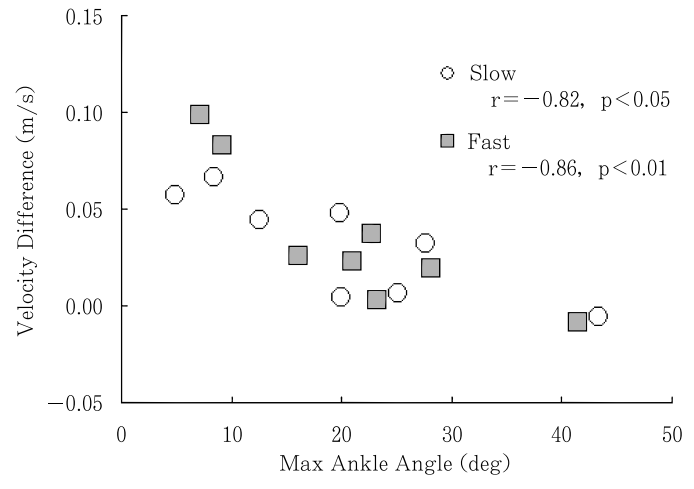

Fig. 5 Relationship between max ankle angle and velocity difference.

ることを意味する，そのため，足関節底屈角度を $1^{\circ}$ 増加させるだけでも長水路の $50 \mathrm{~m}$ のレースで 0.02 から $0.06 \mathrm{~s}, 200 \mathrm{~m}$ のレースで 0.08 から $0.24 \mathrm{~s}$ の記録短縮が見込めることになる．競泳競技では 100 分の 1 秒で勝敗を分けることもあるため, 水 中ドルフィンキックのみならずレースパフォーマ ンスの向上において足関節底屈角度を増加させる ことは重要である.

被験者本来の足関節の動的な柔軟性と足関節の 底屈角度増加に伴う泳速度変化との間に有意な負 の相関関係が認められた (Fig. 5) ことから, 本来 の底屈角度が小さい選手ほど底屈角度を増加させ るトレーニングによって泳速度の向上が期待で き, 本来の底屈角度が大きい選手ほど泳速度向上 があまり見込めないことが示された．本研究で足 関節最大底屈角度が最も大きかった被験者 Wに おいては, 底屈角度の増加に伴って泳速度は低下 し, $10 \mathrm{~m}$ 所要時間は延長していた (Table 1).こ の泳速度減少は, 底屈角度増加に伴う足部の推進 力低下によるものであると考えられる（Table 2). 推進力は膝の伸展動作時に足関節が底屈する ことにより水が後方へと押し出されて発揮されて いる（Maglischo, 1993, pp. 426-428).つまり, 膝 の伸展動作時に足関節が底屈することにより, 足 部の運動方向と水を押し出す足の甲の面との間に 角度（以下「迎え角」と略す）が生じることで水 は後ろに押し出され, そのときに足部に働く力の 水平成分である抗力によって身体は前に推進す
る。よって，被験者 $\mathrm{W}$ において足関節底屈角度 増加に伴う足部の推進力低下は, 膝伸展動作時の 足部の迎え角の増加により足部に働く抗力成分が 減少し，その結果推進力が低下したことになる。 逆に他の被験者は, 膝伸展時の足関節底屈角度増 加によって迎え角が増加した結果, 足部に働く抗 力成分が増加して推進力が増加したことになる. これらを考慮すると, 足部で効果的に推進力を得 るには膝伸展時の足部の迎え角が重要であり, 迎 え角には推進力を効果的に得るための最適な角度 が存在すると考えられる.下半身だけで考える と, 足部の迎え角は大腿部, 下腿部, 足部, 全て の角度に依存するため, 水中ドルフィンキック中 の足部の迎え角を大きくするには股関節最大伸展 角度ならびに膝関節最大屈曲角度を大きくし, 足 部の迎え角を小さくするには股関節最大伸展角度 ならびに膝関節最大屈曲角度を小さくする必要が ある。つまり, 足関節最大底屈角度が大きな選手 は股関節と膝関節の運動範囲を小さくし，底屈角 度が小さな選手は運動範囲を大きくしなければ推 進力を効果的に得る足部の迎え角にならない。し かし, 股関節伸展角度を大きくすると前面から受 ける大腿部の抵抗は大きくなる。 そのため, 推進 力獲得と避抵抗の両方を考慮すると, 足関節最大 底屈角度は大きく, 股関節と膝関節の運動範囲は 小さな水中ドルフィンキックが効率もよく速いと 考えられるため, 大きな足関節最大底屈角度は高 い泳速度を実現させることに対する重要な要因で ある. 動作分析から求めた泳中の足関節最大底屈 角度と泳速度との間に, Slow $(r=0.11, p>0.05)$ と fast $(r=-0.29, \mathrm{p}>0.05)$ 両試技で有意な相関 関係は認められなかったが，これは水中ドルフィ ンキックのパフォーマンスを決定付ける重要な要 因が足関節底屈角度だけではないことを示してお り, 迎え角の観点から考えると, 他の要因の一つ としては足関節底屈角度に応じた股関節と膝関節 の運動範囲の適応が挙げられる。しかし, 足関節 底屈角度に応じて股関節と膝関節の運動範囲を適 応させることで足部の推進力が増加し, 泳速度が 向上するか否かについては更なる調査が必要であ る。 


\section{$\mathrm{V}$ 要 約}

本研究の目的は, 水中ドルフィンキック泳中の 足関節底屈角度だけを増加させたときの泳速度変 化の分析と, 泳中の最大底屈角度と泳速度の関係 を調查することにより, 泳中の足関節底屈角度と パフォーマンスとの関係を明らかにすることで あった。

本研究から得られた結論は以下の通りである.

（1）足関節底屈角度が増加することで水中ドル フィンキック泳中に足部のみで発揮される 推進力が増加し, 結果として泳速度は向上 した。

（2）足関節の底屈方向への柔軟性は水中ドル フィンキックのパフォーマンスにおいて重 要であるが, パフォーマンスを決定付ける 要因ではないことが示された。

（3）足関節底屈角度の増加に伴う泳速度の向上 は, 足関節底屈方向への柔軟性が低い選手 ほど大きくなるという相関関係が認められ た。

\section{文献}

Abel, R., Anto'nio, S., Luis, L., Jorge, R. and Francisco, A. (2006) The effect of swimmer's hand/ forearm acceleration on propulsive forces generation using computational fluid dynamics. Journal of Biomechanics 39 (7) : 1239-1248.

阿江通良・湯 海鵬・横井孝志（1992） 日本人アス リートの身体部分係数の推定. バイオメカニズム, 11.

Berger, M.A.M., de Groot, G. and Hollander, A.P. (1995) Hydrodynamic drag and lift forces on human hand/arm models. Journal of Biomechanics, 28 (2) : 125-133.

Bixler, B.S. and Riewald, S. (2002) : Analysis of swimmer's hand and arm in steady flow condi- tions using computational fluid dynamics. Journal of Biomechanics, 35 : 713-717.

Counsilman, J.E. (1977) Competitive swimming manual for coaches and swimmer. Pelham Books ; London, pp. 125-129.

Maglisco, E.W. (1993) Swimming even faster. Mayfield Publishing Company : California.

Mookerjee, S., Bibi, K.W., Kenney, G.A. and Cohen, L. (1995) Relationship between isokinetic strength, flexibility, and flutter kicking speed in female collegiate swimmers. Journal of Strength and Conditioning Research 9 (2) : 71-74.

中島 求・佐藤 憲 · 三浦康郁 (2005) 全身の剛体 動力学と非定常流体力を考慮した水泳人体シミュ レーションモデルの開発. 日本機械学会論文集, B (71).

大庭昌昭・金岡恒治・萬久博敏・野村武男（1995） 足部の柔軟性がバ夕足に及ぼす影響について，筑 波大学運動学研究, $11: 89-95$.

Sanders, R.H. (1999) Hydrodynamic characteristics of swimmer's hand. Journal of Applied Biomechanics, $15: 3-26$.

Schleihauf, R.E., Higgins, J.R., Hinrichs, R., Luedtke, D.L., Maglischo, E.W., Maglischo, C.W. and Thayer, A.L. (1988) Propulsive techniques: front crawl stroke, butterfly, back stroke, and Breaststroke. In : Ungerechts, B.E., Reischle, K. and Wilke, K. (Eds.) Swimming Science V. Human Kinetics : Champaign, pp. 53-59.

Sugimoto, S., Nakashima, M., Ichikawa. H. and Nomura. T. (2006) Estimation of thrusts generated by each body part during underwater dolphin kick using "SWUM". In : Vilas-Boas, J.P., Alves, F. and Marques, A. (Eds.) Biomechanics and Medicine in Swimming X. Portuguese Journal of Sport Sciences : Porto.

高木健太郎・岡本彰祐編 (1968) 生理学大系 II. 医学 書院 : 東京, pp. 813-816.

$\left(\begin{array}{l}\text { 平成 } 19 \text { 年 } 5 \text { 月 } 10 \text { 日受付 } \\ \text { 平成 } 19 \text { 年 } 10 \text { 月 } 13 \text { 日受理 }\end{array}\right)$ 